\title{
Fossiler fra Faxe Kalkbrud
}

Anmeldt af Geologisk konservator Søren Bo Andersen, Geologisk Institut Aarhus Universitet

Jeg ved ikke, hvor stort førsteoplaget af denne lille bog er, men jeg gætter på, at det ikke kan vare længe, førend man må gå i gang med næste oplag. Denne bog er et "must" for alle, som interesserer sig for danske fossiler i almindelighed og for Danienfossiler fra Faxe Kalkbrud i særdeleshed.

Familien Rasmussen i Fakse omfattende den ene af forfatterne, Alice Rasmussen, og sønnen Leif Rasmussen er i sten- og fossilsamlerkredse kendt for at have formidable samlinger fra især de sjællandske kridt- og kalklag.

Alle dyregrupper fra Faxe repræsenteret I denne lille bog, som forfatterne selv kalder for et "billed-atlas", har vi mulighed for at nyde dele af den omfattende samling af fossiler fra Faxe Kalkbruds lag af koralkalk og bryozokalk. Fossilerne er dels bevarede skaller og skeletdele af calcit og dels aftryk i den hårde kalksten efter nu opløste (især snegle-) skaller. Forfatterne har fremstillet siliconegummi-udfyldninger af disse huller, således at vi nu ser snegle- og muslingeskallerne, som de oprindeligt så ud. Disse afstøbninger er af fotograferingstekniske grunde blevet pudret med det gulligbrune limonit-pulver. I billed-atlasset bringes omkring 200 virkeligt gode fotografier, hvoraf

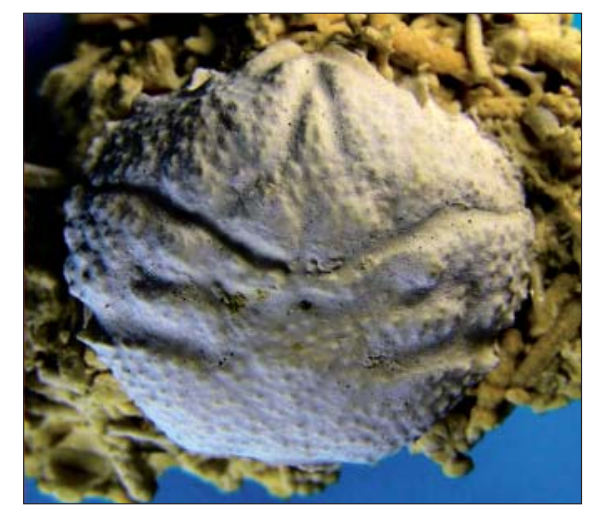

Krabben Dromiopsis rugosa- den mest almindelige krabbe, som mange har fundet på fossiljagter i Faxe Kalkbrud. (Foto fra bogen)

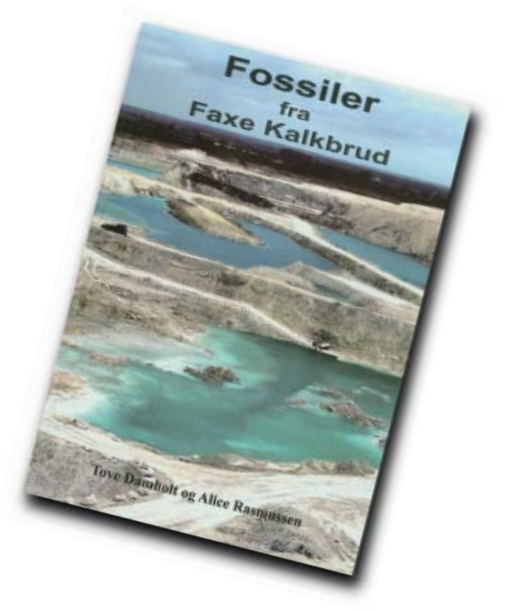

mange er nærfotos, som viser fine detaljer og strukturer på fossilerne.

Alle dyregrupper, som er kendt i Faxe Kalkbruds lag, er repræsenteret i bogen, om end de nok ikke er repræsenteret her i samme forhold som i naturen. For eksempel er der mange flere snegle, og især en mængde meget små arter, der ikke har fundet plads i bogen. Især store og spektakulære sneglearter vises. Og det skal siges, at mange af de viste billeder er meget bedre end det, der tidligere er bragt i både hel- og halvvidenskabelige arbejder.

Krabberne er meget smukt repræsenteret med meget flotte eksemplarer. Den overvejende del af fossilbillederne er navngivet med gruppe, slægts- og eventuelt artsnavn. Og hurra!, ved alle billeder er det angivet, hvad størrelsen af fossilet er, og yderligere kan det ved et antal på 1, 2 eller 3 stjerner være angivet, hvor sjældne visse af fossilerne er i Faxe Kalkbrud.

\section{Billed-atlas til turen}

Dette billed-atlas hører til ved enhver tur til Faxe Kalkbrud eller til bagefter, når fundene skal bestemmes. Fossiludvalget er meget typisk for det, man ville forvente af et fortidigt koralrev i et varmt hav. For studerende og andre, som interesserer sig for fossile faunaer, vil nærværende bog fint kunne indgå som en dokumentation af revets faunasammensætning. For tiden antages det, at hvis man tæller alt med fra foraminiferer til krokodiller, når man måske op i nærheden af 750 forskellige arter, så når bogen bringer 200 billeder, hvoraf der selvfølgelig artsmæssigt er gengangere, er det virkelig en god del af det, man normalt ville forvente at kunne finde.

Forfatterne viser derudover nogle meget karakteristiske og nogle meget specielle fossiler, som man måske næppe finder selv, men som vi heldigvis her har fået mulighed for at se.

Der er meget lidt tekst i bogen - Faxefaunaen placeres tidsmæssigt og klimamæssigt, og der fortælles lidt om de forskellige stenarter - det er alt, men det gør slet ikke noget, for det er billedmængden og billedkvaliteten sammen med navngivningen, som gør denne bog så brugbar, ja værdifuld for den fossilinteresserede - og så vil den nok være forholdsvis let at bruge selv for udlændinge, som ikke mestrer det danske sprog. Måske vil det dog alligevel være formålstjenligt i et kommende oplag at internationalisere bogen lidt mere ved at bringe overskrifter og gruppenavne på flere sprog (tysk og engelsk).

Med den lave pris på bogen (65 kr.) må den oplagt blive en bestseller.

Fossiler fra Faxe Kalkbrud af Tove Damholt og Alice Rasmussen. Format: $15 \mathrm{~cm}$ x $21 \mathrm{~cm}$ Udgivet af Østsjellands Museum, 2005. 44 sider, pris: 65 kr. ISBN 87-983945-7-6

Yderligere info om familien Rasmussens samling af bl.a. Faxe-fossiler: http://leif.r.hjem.wanadoo.dk/index.htm (Leif Rasmussens hjemmeside) 